\title{
堀川の流れと水質に関する現地調査 OBSERVATION STUDY ON WATER FLOW AND WATER QUALITY IN HORI RIVER
}

\author{
武田 誠 1 松尾直規 2 \\ Makoto TAKEDA and Naoki MATSUO \\ 1正会員 博士 (工） 中部大学助教授 工学部土木工学科（干487-8501 愛知県春日井市松本町1200) \\ 2フェロー 工博 中部大学教授 工学部土木工学科（干487-8501 愛知県春日井市松本町1200）
}

\begin{abstract}
Rehabilitation of the water quality in Hori River located at Nagoya city has been a long outstanding problem. In this study, the characteristics of water flow and water quality in Hori River are evaluated for this problem by use of observation data. Firstly, the characteristics of water flow and salinity change in spring tide and neap tide are discussed. Secondly, the characteristics of turbidity and DO distribution concerning with tidal flow are evaluated. From these studies, it is found that the water flow is influenced by riverbed shape and vertical mixing causes desstratification and DO value increasing in flood tide of spring tide. Moreover, high turbidity at bottom in spring tide and high turbidity at middle layer in neap tide are also clarified. On the other hand, it is found that effect on DO value of aeration facilities at Nayabashi is limited neighborhood of the facilities, and the inflow from Nakagawa Canal may affect water quality change in the downstream of Hori river.
\end{abstract}

Key Words : Observation, Hori river, Water flow, Water quality, DO

\section{1. はじめに}

名古屋市の中心街を南北に流れる堀川は，名古屋城築 城において掘削された川であり，当時は運河としての機 能を有し，岸辺も非常に賑わっていたと報告されている。 その後，いくつかの改修を重ね，現状では堀川上流を流 れる黒川と猿投橋から下流の堀川として都市河川の形態 を成している (図-1参照)。堀川の下流では新堀川と合 流して名古屋港へ注いでいる. 堀川は，「臭い」「污 い」という負のイメージを持っているものの，行政や多 くの市民団体が水環境改善のために様々な努力を行って おり，堀川の水質改善に向けての機運が高まっているが， 十分な改善はなされていない. 堀川の水質悪化の要因と して, 次の 4 つが挙げられる.

1）自己流量が存在せず，庄内川から導水が行われてい

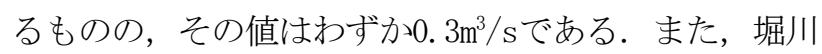
流域からは，下水処理水が流入し，これが堀川の淡水流 入として支配的である.

2）堀川流域は合流式下水道であるため，降雨時に雨水 吐から多量の雨水および未処理水が流入し，污濁負荷を 増大させる.

3）堀川の下流は名古屋港とつながっており, 河口から 上流の猿投橋までは感潮河川である. したがって, 名古
屋港の劣悪な海水の影響を多大に受ける.

4）これまでの負荷量の蓄積および底層の嫌気化により 底泥がへドロ化している，それにより金属類や悪臭物質 の溶出が生じ，水質悪化の一因となっている.

本研究では堀川中流部および下流部を対象に，2004年， 2005年，2006年の夏季の現地観測結果から，水質改善の ための基礎資料となる流れと水質の実態とその特徵につ いて明らかにすることを目的としている.

\section{2. 堀川中流部の現地観測}

\section{1 観測概要}

堀川において最も人通りの多い活気のある場所は，納 屋橋周辺の中流部である. そこで, 堀川中流部の水理・ 水質特性を把握するために，2004年8月にADCP（RD Instruments社）を用いた流速観測と多項目水質観測装 置クロロテック（アレック電子社）を用いた水質測定を 行った。流速観測区間は，図-2に示す洲崎橋（河口から $8.4 \mathrm{~km})$ 〜五条橋 $(10.0 \mathrm{~km})$ であり，水質観測はその間の 天王崎橋, 納屋橋, 錦橋, 桜橋, 中橋で行った. 観測日 時は表-1に示すとおりであり，満潮，下げ潮（満潮から 干潮への中間），干潮，上げ潮（干潮から満潮への中 
表-1 観測日時

\begin{tabular}{|c|c|c|c|}
\hline \multirow{2}{*}{ 大潮 } & 2004年8月2日 & 2004年8月16日 & 2005年8月6日 \\
\cline { 2 - 4 } & 時刻 & 時刻 & 時刻 \\
\hline 満潮 & $6: 28$ & $5: 46$ & $6: 14$ \\
\hline 干潮 & $13: 15$ & $12: 24$ & $12: 53$ \\
\hline \multirow{2}{*}{ 小潮 } & 2004 年8月11日 & 2004 年8月25日 & 2005 年9月27日 \\
\cline { 2 - 4 } & 時刻 & 時刻 & 時刻 \\
\hline 満潮 & $16: 15$ & $14: 56$ & $15: 39$ \\
\hline 干潮 & $8: 49$ & $7: 06$ & $7: 30$ \\
\hline
\end{tabular}

間）を意識して観測している. ADCP観測，水質観測とも に河川中央点で測るように注意した．また，同様の水質 観測を，2005年にも実施しており，計測装置として多項 目水質測定装置（WQC-24; 東亜DKK社）を用いた。観測 日時は表-1のとおりであり，2005年は上記の観測場所に， 下流に位置する新州崎橋, 大瀬子橋を加えた.

\section{2 塩分分布}

2004年8月における大潮の塩分分布を図-3 (a) に示す. 本図から，満潮時では表層と底層に密度差が生じている ことが分かる。下げ潮時から塩分濃度が低くなり，干潮 時ではさらに低くなるとともに表層と底層の塩分差が小 さくなっている.これは海水が流下寸ることにより，上 流からの淡水の影響を受けて塩分值が低下し，さらに水 位が下がって表層と底層の水が混合することによるもの と考えられる. また，上げ潮時になると海水が遡上する ため，下流から塩分が高くなるが，塩分分布は鉛直一様 となる. 同様な塩分分布の推移が他の大潮の観測結果に もみられたことから，ここで示した塩分分布の変化が大 潮時の特徵と考えられる.

2004年8月 25 日における小潮の塩分分布を図-3(b) に示 す. 小潮時の塩分分布は, 潮汐の干満の差が大潮時より も小さいため時間的な変化は小さい，満潮時，下げ潮時 では表層と底層の塩分濃度の差が大きい，干潮時におい ても下流へ塩水が押し出されて塩分值が小さくなってい るが，底層に塩分が残り鉛直方向に塩分濃度の差が生ま れ，成層も存在している．上げ潮時では海水が下流から 遡上し塩分值が上昇し始める. しかし，図-3(a)の大潮 時のように鉛直一様の混合形態で遡上することはなく， 弱混合から緩混合の状態で成層を形成したまま上流へ塩 水が流入している。したがって，小潮では常に成層が形 成されている状態であり，これが大潮と小潮の違いであ ると考えられる.

\section{3 流速分布}

2004年8月 16 日における大潮の下げ潮および上げ潮の 流速分布を図-4 (a) に示寸，なお，堀川が南北に位置し ていることから流速の南北成分を取り上げ，北方を正 （図中の赤色）で示している. 流速分布の時間および空 間分布をみてみると，大潮の場合，下げ潮時には表層の

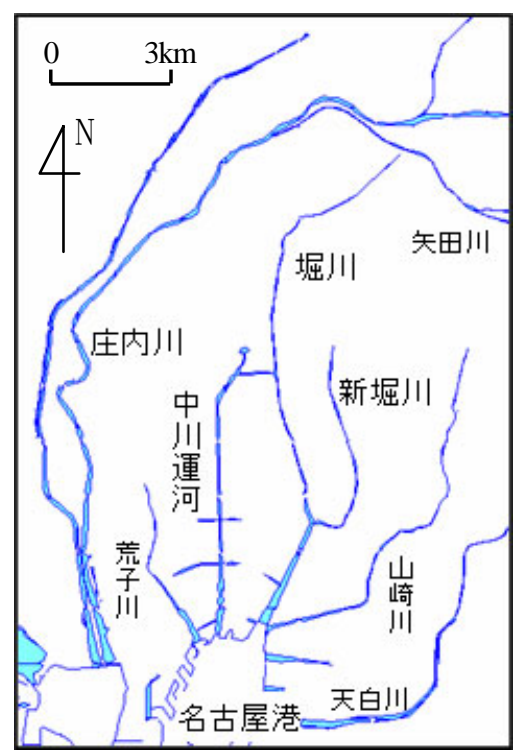

図-1 名古屋市周辺の河川
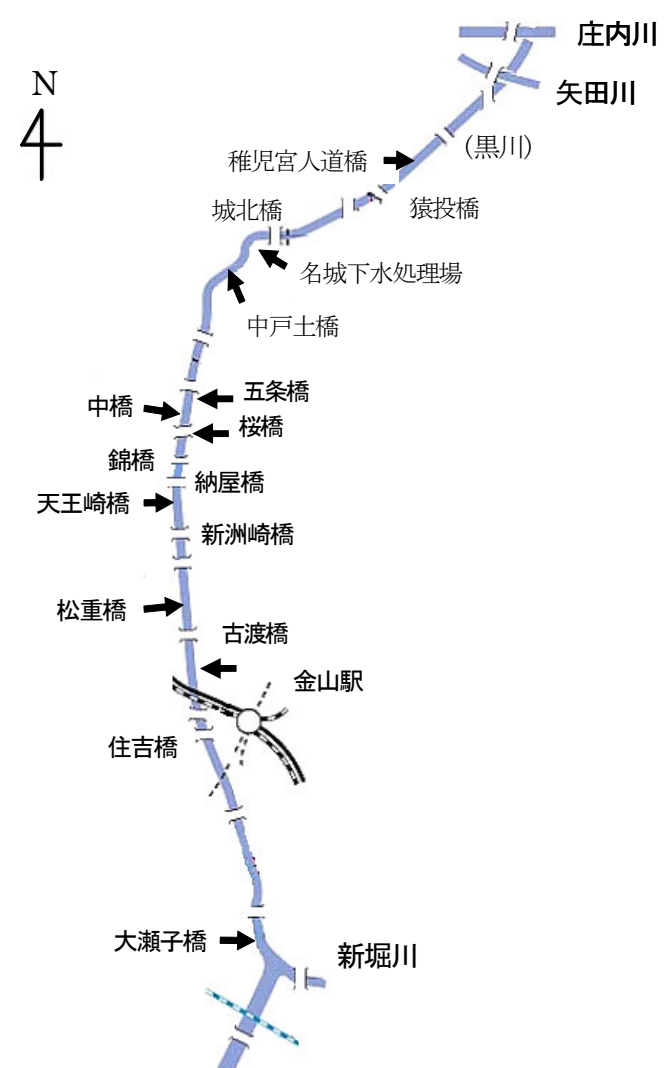

堀川

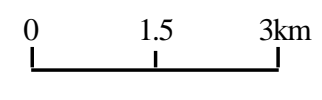

図-2 観測場所

方が底層に比べて流下寸る流速が大きくなっていた．こ こで，図-4(a)に示寸ように，流速值の分布にあわせて 線を引いてみれば，その線は河床の堆積部を連ねた線と 

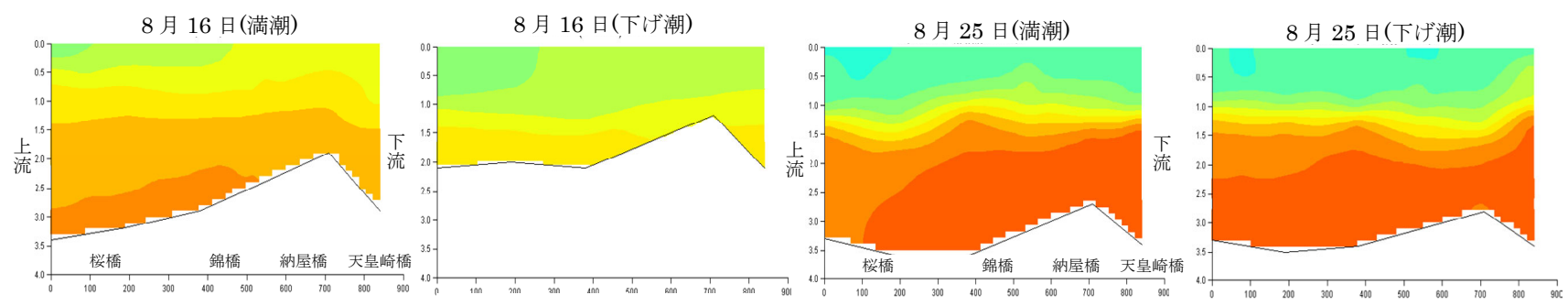

8 月 16 日 (干潮 $)$

8 月 16 日(上げ潮 $)$
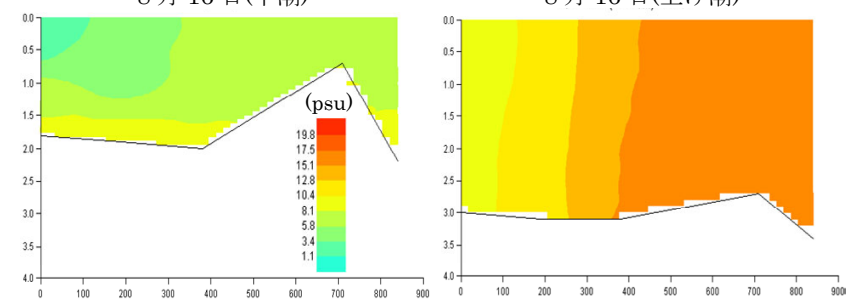

8 月 25 日 (干潮)

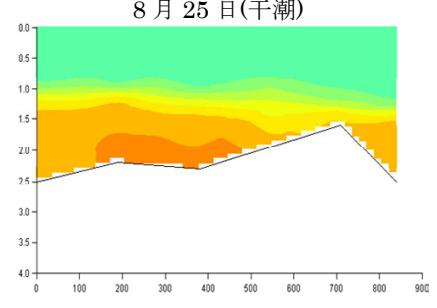

8 月 25 日(上げ潮)

(a) 大潮の場合

（b）小潮の場合

図-3 塩分の空間分布
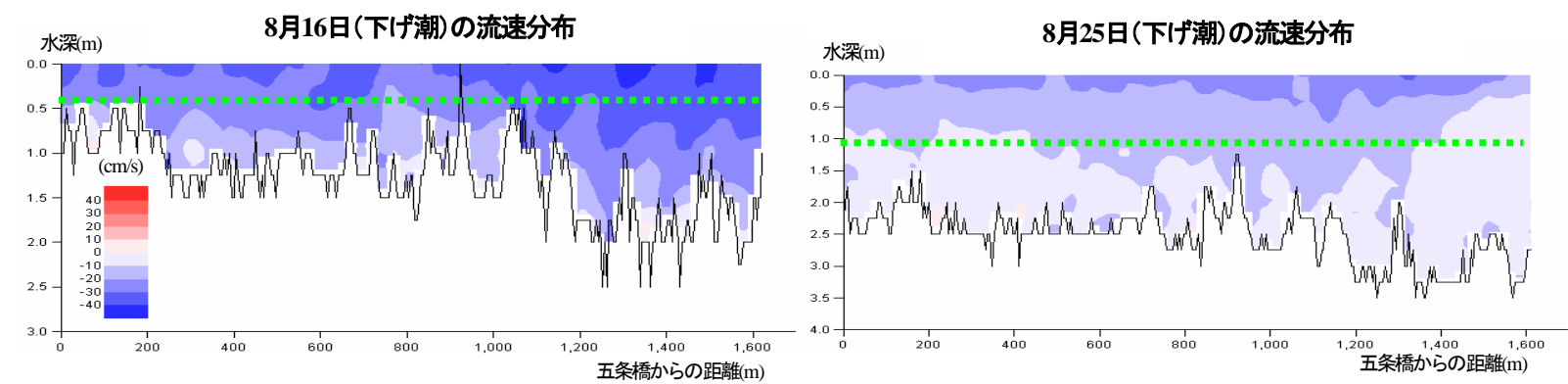

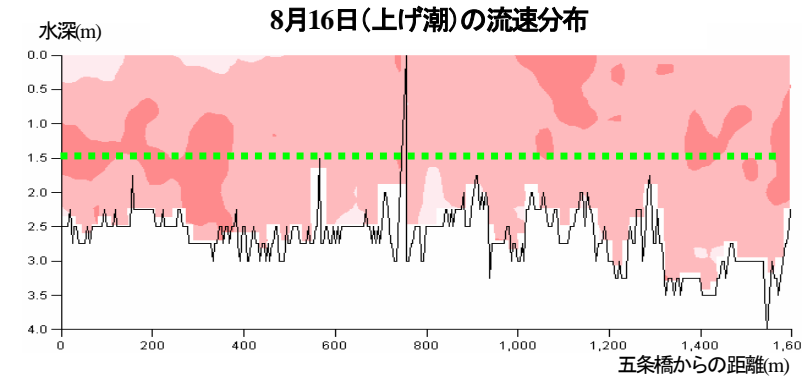

(a) 大潮の場合

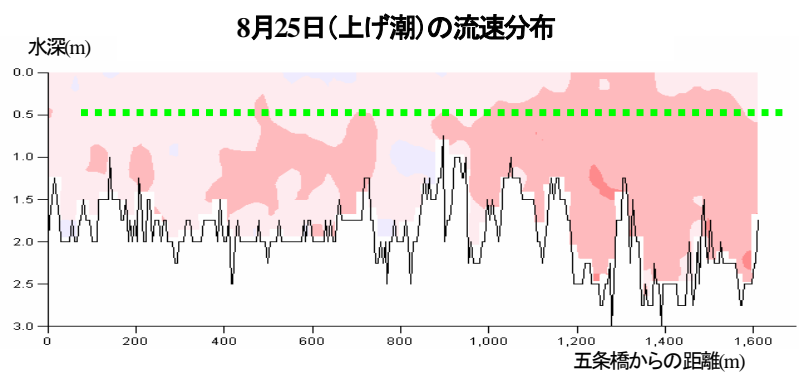

(b) 小潮の場合

図-4 流速分布

同様であることが分かる．また，上げ潮時は鉛直一様で あり，図-3(a)の強混合状態で塩水が遡上していること が反映された結果となっている。ここで，上げ潮の場合 も，下げ潮の場合と同様に，河床の堆積部を連ねた線を 記したが，上げ潮の場合は，このような線に対して流速 值が変化しているとはいえない。これは，密度流の現象 により塩水が潜り込み，鉛直方向の流速差が無くなった ためであると考えられる。

2004年8月 25 日における小潮の下げ潮および上げ潮の 流速分布を図-4 (b) に示寸。小潮の場合，潮汐の影響が 小さいため大潮の場合と比べると全体的に流速值が小さ い. 図-3 (a) と同様に, 流速值の分布に合わせて線を引 いてみれば，上げ潮の場合には，その線は河床の堆積部
を連㸚た線と同様であり，大潮の場合と同じように，地 形の影響を受けて流速值が変化していることが推察され る.さらに, この場合, 河床の堆積部が流れを阻害し, 成層化を促進させているため, その影響が流速值に現れ ているものと考えられる．また，上げ潮の場合，河床の 堆積部を連ねた線の底部で流速が大きくなっている傾向 が認められる．これは，緩混合状態で遡上寸る塩水密度 流の影響が強く現れている結果である。このように，本 観測結果から, 縦断方向の河床形状の変化が流速值に影 響を与えていることが示された。

\section{4 濁度とDOの分布}

2004 年8月 16 日の大潮の干潮と 2004 年 8 月 25 日の小潮の 


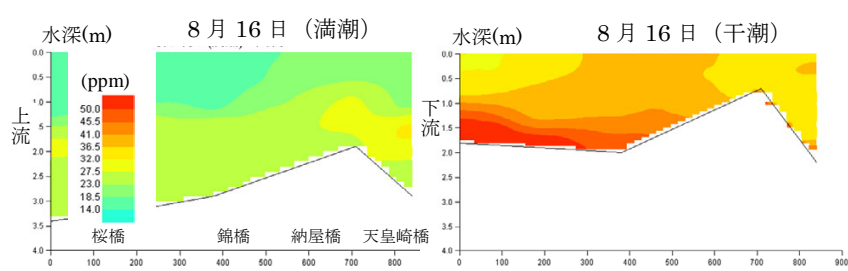

(a) 大潮の場合
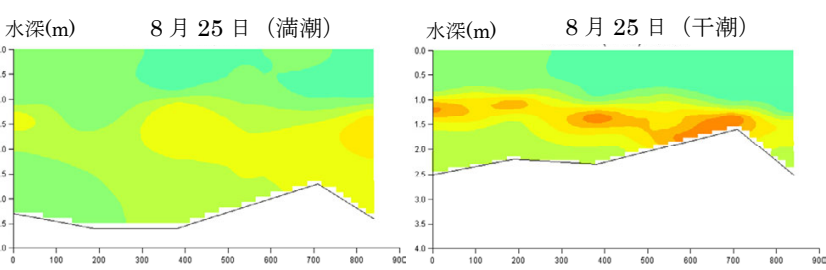

(b) 小潮の場合

図-5 濁度の空間分布
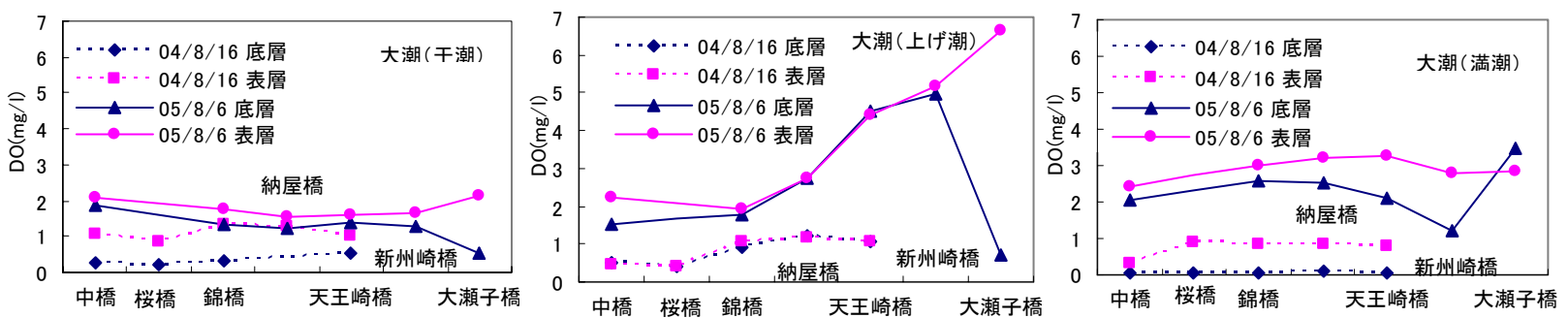

(a) 大潮の場合
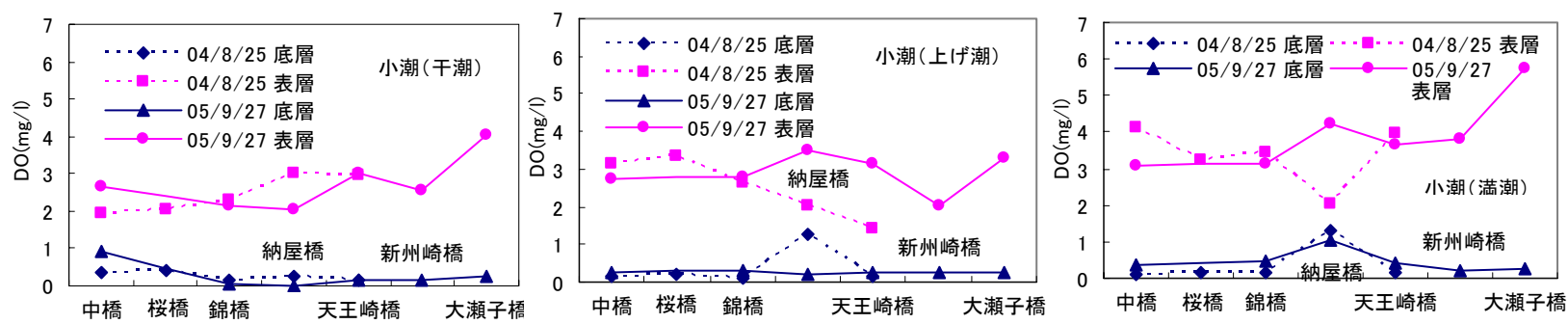

（b）小潮の場合

図-6 DOの空間分布

干潮の濁度分布をそれぞれ図-5 (a) と (b) に示す. 図一 5 (a) から大潮の場合は底層で，図-5(b) から小潮の場合 は中間層で高い濁度の分布が見られる，大潮の場合は流 れも強く, 水深も浅くなるため底泥の巻上げが大量に生 じ，強混合下であってもその影響によって底層の濁度が 大きくなったものと考えられる. 一方，小潮の場合は， 緩混合下において巻き上げられた濁質が密度成層境界面 に集積しており，底泥の巻き上げによって生じた濁りの 分布は, 混合状態により異なる傾向がみられた.つぎに, 図-6 (a)に大潮の場合として，2004年8月16日と2005年8 月6日の, 図-6(b)に小潮の場合として，2004年8月25日 と2005年9月27日のDOの空間分布を示す.これらの図 から, 夏季の堀川中流部では全体的にDO值が低く, 貧 酸素状態にあることがわかる．また，大潮の場合は，多 くの場合底層におけるDO值が小潮時と比べるとやや高 く, 特に上げ潮においては, 表層と底層のDO值がほぼ 等しくなっているのに対し，小潮時では，す心゙ての時間 で底層のDO值がゼロに近い状態のまま変化が無いこと がわかる，また，図-6から，大潮の場合，2004年と2005 年で值やその分布に大きく差が生じている.この原因と して，2005年8月6日の大瀬子橋におけるクロロフィルa
の值が最大で $81 \mu \mathrm{g} / 1$ と高かったことから，2005年8月6 日のDOの状況は, 名古屋港における植物プランクトン の増殖および光合成活動の活発化により, DOの高い水 が河口から流入したことによる影響と考えられる．一方， 小潮の場合，表層および底層のDO值が2004年と2005年 でほぼ同程度の值を示しており，小潮では常に底層のD $\mathrm{O}$ 值が低く維持されていることが分かる。.また，上げ潮 や満潮時には下流側一進むに連れて, 表層のDO值が大 きくなる傾向にあるが，これは名古屋港の表層水が植物 プランクトンの光合成により DO值が高いことによるも のと考えられる. また, 納屋橋周辺でDO值が増加して いるが，これは名古屋市により設置されたDO供給装置 の効果である. ただし, 本観測結果から, 錦橋, 天王崎 ではDO值の増加がみられないことから，その影響範囲 は狭いものと考えられる。

\section{5 堀川中流域における水理・水質特性}

得られた観測結果から堀川中流域の水理特性と水質特 性をまとめると次のようである.

1）大潮の場合，満潮から下げ潮になると表層の流れは 大きくなるが，底層の流れは河床形状の影響を受けて小 

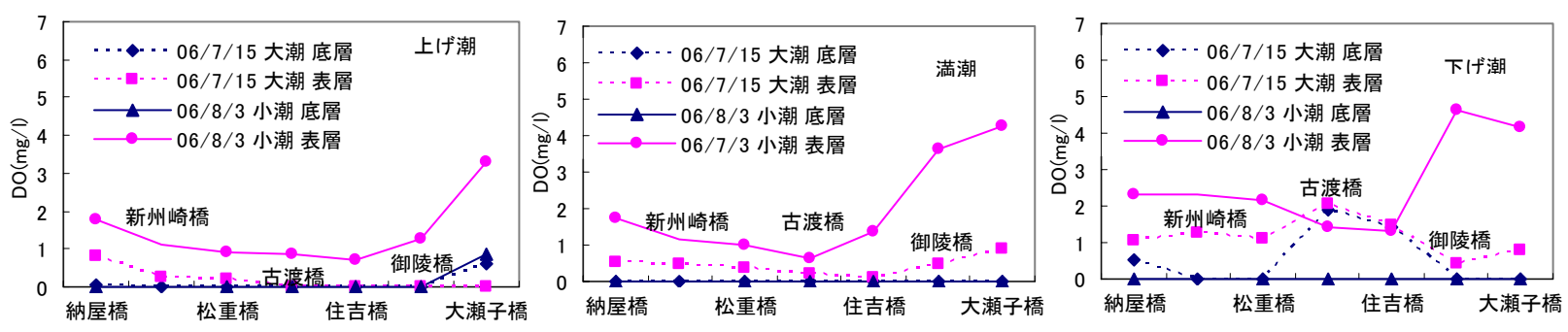

図-7＼cjkstart堀川下流におけるDOの分布
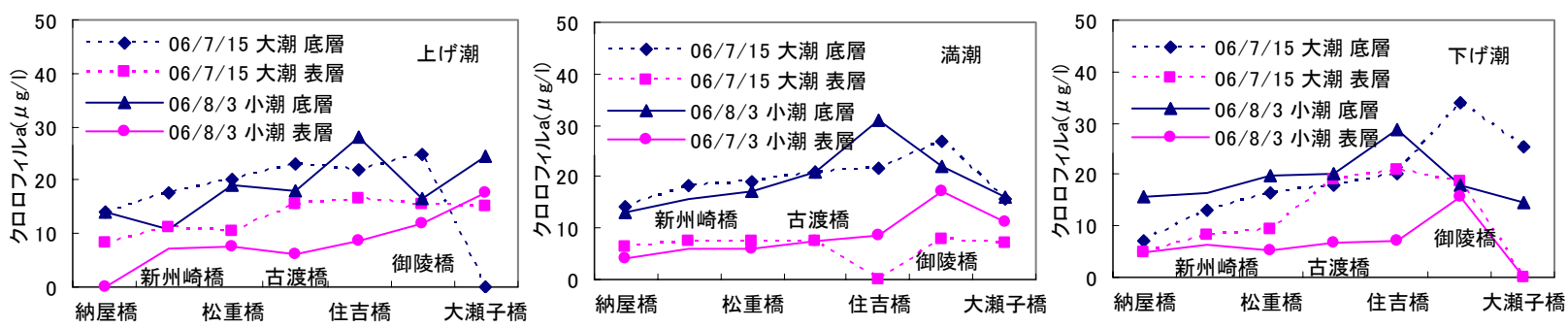

図-8＼cjkstart堀川下流におけるクロロフィルaの分布

さくなる，これにより全体で淡水化が進むものの，表層 は早く淡水に置き換わるため表層と底層で塩分差が生じ る.さらに，時間が過ぎれば流速が速くなることと水深 が浅くなることにより，特に河床の凸部で鉛直混合が生 じる．上げ潮時では納屋橋付近の凸部により表層と底層 の水が混合し，さらに下流側の鉛直混合した海水が遡上 してくるため，鉛直一様の強混合で上流一流れる.

2）小潮の場合は大潮の場合よりも全体的に流速值が小 さいため干潮時に河床の凸部で鉛直混合が生じにくく, 常に密度成層が維持されること，満潮や干潮付近では表 層と底層で流れの逆転がみられ，上げ潮時には緩混合状 態で海水は河床に沿って遡上することが特徵として挙げ られる. これらは小潮に流速值も小さくなり，水深も極 端に浅くならないため，鉛直混合が生じにくくなり密度 流の影響が卓越するためと考えられる.

3）濁度については，水深が浅くなり掃流力が増寸干潮 時に值が高くなるが，大潮の場合は巻き上げられた濁質 が沈降しながら拡がるため底層に集積し，小潮の場合は 成層境界面が沈降を妨げるため，そこに濁質が集積する 現象が特徵的である.

4）DOについては，小潮時では底層のDOが常に低く 貧酸素状態で推移しているのに対し，鉛直混合が生じる 大潮の上げ潮では表層と底層のDOがほぼ一様化するが, その濃度レベルは低い。

\section{3. 堀川下流部の現地観測}

\section{1 観測概要}

堀川下流部の水質変化を把握寸るために，2006年夏季 に納屋橋，新洲崎橋，松重橋，古渡橋，住吉橋，御陵橋， 大瀬子橋で水質観測を実施した。観測方法は2004年観測
表-2 観測日時

\begin{tabular}{|c|c|c|c|}
\hline \multirow{2}{*}{ 大潮 } & 2006年7月15日 & \multirow{2}{*}{ 小潮 } & 2006年8月3日 \\
& 時刻 & & 時刻 \\
\hline 満潮 & $8: 30$ & 満潮 & $12: 24$ \\
\hline 干潮 & $15: 00$ & 干潮 & $5: 33$ \\
\hline
\end{tabular}

と同様である，観測日時を表-2に示す，ただし，2006年 7月15日の干潮時は計測できていない.

\section{2 観測結果}

図-7と図-8に，それぞれDOとクロロフィルaの空間 分布を示す．まず，図-7から，2006年7月15日ではDO 值が非常に小さいことが分かる. 2006年8月3日も小さい DO值であるが，表層は1～2mg/1の值を示しており，こ れは前述したように，小潮時の成層発達に伴い底層との 混合が抑制されたことから，表層のDO值が底層の影響 をあまり受けなかったことによるものと考えられる。ま た，図-7で特徽的なことは，2006年7月15日の下げ潮に おける古渡橋，住吉橋におけるDOの上昇である。ここ で，図-8に示したクロロフィル a を見てみると，下げ潮 時の古渡橋, 住吉橋で值は高いものの, 他と比心゙て際 立って高くはなく，植物プランクトンの光合成により， その箇所のみがDOが高まったとは考えにくい.このD $\mathrm{O}$ 上昇は下げ潮時に生じていることから，古渡橋とその 上流に位置寸る松重橋との間に原因があるものと推察し, その間に位置する中川運河から堀川几導水している松重 ポンプの状況を調べた.この日の導水は9時 30 分から 2 時 40分の間に $7.4 \mathrm{~m}^{3} / \mathrm{s}$ の流量であり，そのDO值が $6.7 \mathrm{mg} / 1$ であった。一方，下げ潮時の堀川（松重橋）の流量は $27.7 \mathrm{~m}^{3} / \mathrm{s}$ であり，その時のDO平均值は $0.6 \mathrm{mg} / 1$ であっ 
た.これらの值から，単純な収支計算で中川運河からの 導水が合流した後のDO值を求めると約 $1.9 \mathrm{mg} / 1$ であり, この值は下流側の古渡橋で観測された值とほぼ等しかっ た.このことから，上述した古渡橋のDO上昇は中川運 河からの導水の影響によるものと推察され，中川運河か らの導水の影響が導水箇所のみでは無く，広く影響を与 えていることが示された. なお，冬期における堀川のD O変化は中川運河の影響を大きく受けることが報告され ており ${ }^{2}$ ，夏期においても同様の傾向を示していること が確認された. ただし，流入した高DO水のその後の変 化が確認されておらず, この解明が今後の課題として 残っている.

\section{4. おわりに}

本研究で得られた成果をまとめれば以下のようである. 1）堀川中流域では河床形状の影響があり，大潮の場合， 上げ潮時に鉛直混合が進み成層構造が壊れるが，小潮の 場合は常に成層構造が維持されていることが示された.

2）濁度の分布から，大潮時には干潮時の底泥の巻き上 げに伴う高濁質が底層にみられ，小潮時には成層境界面 に濁質の集積がみられた。

3） DOの分布から, 大潮の上げ潮時に鉛直混合が生じ 表層と底層のDO值が一致する傾向がみられたが，それ 以外では，表層と底層のDOの差が現れており，特に底
層はきわめてDOが小さい状況が維持されている.

4）納屋橋周辺において，DO供給設備によるDO増加 がみられたが，この影響範囲は狭いことが示された.

5）中川運河からの導水が堀川に大きく影響を与えてお り，高DO水が流入した場合，その影響により堀川内で も高いDO值となっている.ただし, その後, 高DO水 がどのように変化していくのかが今後の課題として残さ れた.

謝辞

本研究は，流域管理と地域計画の連携方策に関わる共 同研究(題目 : 都市河川水質改善のための社会的技術選 定プロセスの設計)の補助を受けて実行されており，関 係各位に謝意を表します。また，本論文に関与する観測 を遂行していただいた当時中部大学工学部土木工学科の 井上慎士氏，久野透氏，日置梓氏，遠山智氏，杉山広明 氏，開地勇介氏，川本拓哉氏に謝意を表します。

\section{参考文献}

1)名古屋市緑政土木局堀川総合整備室 : もつと知りたい 堀川のこと my town my river, 平成14年3月.

2)武田誠, 日置梓, 遠山智, 松尾直規 : 冬季における堀 川の水質変化に関寸る現地観測と数值解析, 環境工学 研究論文集, Vol. 43, pp. 483-491， 2006.

(2006. 9. 30受付) 